\title{
Penerapan Model Pembelajaran Picture And Picture Untuk Meningkatkan Minat Belajar Siswa Pada Pembelajaran Aqidah Akhlak Kelas IV Di MI NW Rumbuk Tahun Pelajaran 2019/2020
}

\author{
${ }^{1}$ Elfa Yuliana ${ }^{2}$ Ahyar Rosidi \\ Institut Agama Islam Hamzanwadi NW Pancor \\ elfayuliana@gmail.com
}

\begin{abstract}
Abstrak
Penelitian ini bertujuan untuk mengetahui peningkatan minat belajar siswa pada mata pelajaran Akidah Akhlak di kelas IV MI NW Rumbuk Tahun Ajaran 2019/2020. Dengan menggunakan model pembelajaran picture and picture dapat meningkatkan minat belajar siswa di kelas IV pada pembelajaran Akidah Akhlak MI NW Rumbuk Tahun Pelajaran 2019/2020.Jenis penelitian yang digunakan adalah Penelitian Tindakan Kelas (PTK) yang dilaksanakan dalam dua siklus. Penelitian ini meliputi empat tahapan yaitu Perencanaan, Pelaksanaan, Observasi dan Refleksi. Teknik pengumpulan data yang digunakan adalah observasi, angket dan tes. Data yang diperoleh dianalisis secara kualitatif untuk menentukan ketuntasan individual dan ketuntasan klasikal.

Hasil penelitian menunjukkan bahwa dari 20 peserta didik pada siklus I pembelajaran menggunakan model pembelajaran picture and picture terdapat masih banyak siswa kelas 4 MI NW Rumbuk, yang tidak tuntas secara individual sehingga ketuntasan klasikal yang dicapai pada siklus I mencapai $60 \%$ dan belum mencapai ketuntasan yang ditetapkan yaitu $70 \%$. Jumlah siswa yang tuntas sebanyak 12 siswa $(60 \%)$ dan siswa yang tidak tuntas sebanyak 8 siswa (40\%) dengan nilai rata-rata $74,75 \%$.

Hasil tersebut menunjukkan bahwa pada siklus I secara klasikal peserta didik belum tuntas sebab peserta didik yang memperoleh nilai $60 \%$ jauh lebih kecil dari presentasi ketuntasan klasikal yang dikehendaki yaitu 70\%. Pada siklus II diperoleh data ketuntasan klasikal sebesar 85\% atau 17 orang siswa memperoleh nilai $85 \%$ dengan rata-rata hasil belajar 76,5 . Hasil pada siklus II tersebut menunjukkan secara klasikal siswa sudah tuntas, sebab siswa yang memperoleh nilai KKM 70\% lebih besar dari ketuntasan klasikal yang dikehendaki yaitu $85 \%$. Berdasarkan hasil penelitian di atas dapat disimpulkan bahwa dengan menggunakan model pembelajaran Picture and Picture dapat meningkatkan minat belajar siswa pada mata pelajaran Akidah Akhlak di kelas IV MI NW Rumbuk Tahun Pelajaran 2019/2020.
\end{abstract}

Kata Kunci: Minat Belajar, Model Picture And Picture, Pembelajaran Aqidah Akhlak. 


\section{PENDAHULUAN}

Pada dasarnya pendidikan adalah laksana eksperimen yang tak pernah selesai sampai kapanpun, sepanjang ada kehidupan manusia di dunia ini. Dikatakan demikian, karena pendidikan merupakan bagian dari kebudayaan dan peradaban manusia yang terus berkembang. Hal ini sejalan dengan pembawaan manusia yang memiliki potensi kreatif dan inovatif dalam segala bidang kehidupannya. ${ }^{1}$

Pendidikan Nasional merupakan pendidikan yang berfungsi untuk mengembangkan kemampuan dan membentuk watak serta peradaban bangsa yang bermanfaat dalam rangka mencerdaskan kehidupan bangsa, bertujuan mengembangkan potensi peserta didik agar menjadi manusia yang bertakwa kepada Tuhan Yang Maha Esa, beriman, mulia, sehat, berilmu, cakap, kreatif, mandiri dan menjadi warga Negara demokratis serta bertanggungjawab

Pada umumnya pembelajaran di MI (Madrasah Ibtida'iyah) dianggap kurang maksimal jika dilihat dari cara guru mengajar, karena pada umumnya seorang guru masih menggunakan sistem pembelajaran yang konvensioanl dan tidak sepenuhnya materi dipahami oleh siswa, sehingga siswa tidak tertarik dengan pengajaran guru yang mengakibatkan siswa enggan untuk mengikuti pembelajaran dengan sungguh-sungguh. Hal ini berpengaruh pada minat dan hasil belajar siswa yang rendah.

Berkaitan dengan masalah tersebut, pada observasi awal ditemukan masalah rendahnya minat belajar siswa terutama pada kelas IV di MI NW Rumbuk. Dimana masalah ini di sebabkan kurangnya perhatian siswa saat guru menjelaskan materi akidah akhlak, media yang digunakan hanya buku paket dan selalu berpegang pada satu metode yaitu metode konvesional. Sehingga menjadikan kurangnya minat dan hasil belajar siswa rendah. Disisi lain sarana prasarana baik berupa alat belajar, media yang digunakan dalam pembelajaran tidak memadai, sehingga siswa hanya sebagai objek penerima materi yang disampaikan oleh guru. Dari paparan di atas sudah jelas bahwa siswa hanya

${ }^{1}$ Hasbullah, Dasar Ilmu Pendidikan (Jakarta: Raja Grafindo Persada, 2005), hlm., 9

${ }^{2}$ UU RI No. 20 Tahun 2003 Pasal 3 Tentang Sistem Pendidikan Nassonal (Bandung: Citra Umbara), hlm. 76. 
sebagai objek penerima apa yang dianggap penting dan menghafal materi-materi yang disampaikan guru.

Dalam penelitian ini model mengajar yang biasa digunakan oleh guru dalam kegiatan sehari-hari disebut model mengajar konvensional. Model pembelajaran konvensional menurut Djamarah adalah model pembelajaran tradisional yaitu dimana proses pembelajarannya lebih dominan ke guru dari pada peserta didik. Model pembelajaran ini ditandai dengan ceramah yang diiringi dengan penjelasan, serta pembagian tugas dan latihan.

Pada saat proses pembelajaran guru menjelaskan materi yang ada, kemudian peserta didik disuruh mengerjakan soal-soal yang ada di buku paket, hal ini yang menyebabkan peserta didik merasa bosan saat pembelajaran, akibatnya peserta didik kurang meminati dalam menguasai materi sehingga menyebabkan rendahnya hasil belajar.

Untuk mengatasi permasalahan tersebut guru dianjurkan untuk memperlihatkan semangat dan menyajikan bahan pelajaran dalam bentuk yang baru agar peserta didik tidak merasa jenuh dan bosan, maka diperlukan model pembelajaran yang menyenangkan dan efektif. Seorang guru atau pengajar membutuhkan keterampilan khusus dalam hal memilih model pembelajaran yang sesuai dengan materi yang diajarkan.

Sehingga dalam penelitian ini, peneliti menaggunakan model pembelajaran Picture And Picture. Model pembelajaran ini merupakan salah satu bentuk model pembelajaran kooperatif yang terdiri dari kelompok-kelompok dengan menggunakan media gambar yang dipasangkan atau diurutkan menjadi urutan logis. Dari model ini siswa diajak secara sadar dan terencana untuk mengembangkan interaksi di antara mereka agar bisa saling asah, saling asih, dan saling asuh. Dan model ini memiliki karakteristik yang inovatif dan kreatif.

Model Pembelajaran ini mengandalkan gambar sebagai media dalam proses pembelajaran. Gambar-gambar ini menjadi faktor utama dalam proses pembelajaran. Sehingga sebelum proses pembelajaran guru sudah menyiapkan gambar yang akan ditampilkan baik dalam bentuk kartu atau dalam bentuk carta 
dalam ukuran besar atau jika di sekolah sudah ada ICT menggunakan Power Point atau Sofware yang lain. ${ }^{3}$

Guru harus terus berupaya melakukan perbaikan dan perubahan dalam sistem pembelajaran khususnya dalam kelas. Reformasi dalam pembelajaran perlu dibangun dan dikembangkan guna menciptakan suasana belajar yang lebih konstruksif, dan demokratis sehingga suasana interaksi kelas baik antara guru dengan siswa maupun siswa dengan siswa itu sendiri dapat tumbuh dan berkembang.

Dalam kegiatan belajar mengajar, interaksi antara guru dan anak didik merupakan kegiatan dominan yang dibarengi dengan media yang digunakan oleh seorang guru. Dalam kegiatan itu, guru tidak hanya mentransfer ilmu pengetahuan, tetapi juga mentransfer nilai-nilai kepada anak didik sebagai subjek untuk belajar. ${ }^{4}$

Berdasarkan asumsi dan alasan-alasan di atas, maka peneliti berusaha mengetahui secara pasti apakah model pembelajaran Picture And Picture dapat meningkatkan minat belajar siswa pada pembelajaran Aqidah Akhlak. Untuk itu peneliti ingin mengetahui bagaimana "Penerapan Model Pembelajaran Picture And Picture Untuk Meningkatkan Minat Belajar Siswa Pada Pembelajaran Aqidah Akhlak Kelas IV Di MI NW Rumbuk Tahun Pelajaran 2019/2020”.

\section{METODE PENELITIAN}

Jenis peneltian ini adalah PTK (Penelitian Tindakan Kelas). PTK yaitu:

1. Penelitian menunjukkan pada suatu kegiatan yang mencermati suatu objek dengan menggunakan cara aturan metodologi tertentu untuk memperoleh data atau informasi yang bermanfaat dalam meningkatkan mutu suatu hal yang menarik minat dan penting bagi peneliti.

${ }^{3}$ http;// Safriadi 094. Biogspot.com/2014/05/ model -pembelajaran. Htm. Tanggal 21-7-2019, Jam 11;45.

${ }^{4}$ Nasution, Berbagai Pendekatan Dalam Proses Belajar \& Mengajar (Jakarta: PT Bumi Aksara, cet. VII, 2000), hlm. 16. 
2. Tindakan menunjukkan pada suatu gerak kegiatan yang sengaja dilakukan dengan tujuan tertentu. Dalam penelitian berbentuk rangkaian siklus kegiatan untuk siswa.

3. Kelas dalam hal ini tidak terikat pada pengertian ruang kelas, tetapi dalam pengertian yang lebih spesifik. Kelas adalah sekelompok siswa yang dalam waktu yang sama, menerima pelajaran yang sama. ${ }^{5}$

Teknik Pengumpulan Data

1. Lembar Observasi.

Lembar Observasi adalah suatu usaha sadar untuk mengumpulkan data yang dilakukan secara sistematis, dengan prosedur yang standar. Mengobservasi adalah suatu istilah umum yang mempunyai arti semua bentuk penerimaan data yang dilakukan dengan cara merekam kejadian, menghitungnya, mengukurnya, dan mencatatnya.

2. Lembar Angket.

Angket adalah sejumlah pertanyaan tertulis yang digunakan untuk memperoleh informasi dari responden dalam arti laporan tentang pribadinya atau hal-hal yang ia ketahui. Dengan angket peneliti dapat mengetahui tingkat minat belajar siswa serta respon siswa terhadap pembelajaran yang disampaikan oleh guru. Angket ini berupa 25 pernyataan yang akan di beri check list oleh peserta didik.

\section{Lembar Tes}

Sekumpulan pertanyaan yang harus dijawab atau tugas yang harus dikerjakan yang akan memberikan informasi mengenai aspek psikologis tertentu berdasarkan jawaban terhadap pertanyaan-pertanyaan atau cara dan hasil subjek dalam melakukan tugas-tugas tertentu. Seperti tes gambar dan isian.

Teknik Analisis Data

1. Data Hasil Belajar

Setelah memperoleh data ketuntasan belajar siswa, maka akan dianalisis dengan menggunakan rumus:

${ }^{5}$ Suharsimi Arikunto, Suhardjono, Supardi, Penelitian Tindakan Kelas (Jakarta: Bumi Aksara, cet. III, 2006), hlm. 3. 
a. Ketuntasan Individu

Persentase Individual $=\frac{\text { Jumlah Skor Prolehan }}{\text { Jumlah Skor Maksimal }} \times 100 \%$

b. Ketuntasan Belajar Klasikal

Ketuntasan klasikal apabila mencapai persentase $70 \%$ atau lebih dari jumlah siswa yang mencapai nilai KKM. Data hasil belajar ini diperoleh dari tes yang diberikan diakhir setiap siklus yang akan diolah dengan perhitungan sebagai berikut: $P=S /{ }_{N} \times 100 \%$

Keterangan:

$$
\begin{aligned}
& \mathrm{P}=\text { Persentase ketuntasan belajar klasikal } \\
& \mathrm{S}=\text { Banyak siswa yang tuntas } \\
& \mathrm{N}=\text { Jumlah seluruh siswa }
\end{aligned}
$$

\section{Data Minat Belajar Siswa}

Untuk mengetahui meningkat atau tidaknya minat belajar siswa, maka dihitung dengan rumus sebagai berikut:

Persentase Individual $=\frac{\text { Jumlah skor yang diperoleh }}{\text { Jumlah skor maksimal }} \times 100 \%$

Adapun data minat belajar siswa ditentukan berdasarkan kriteria sebagai berikut; Sangat Baik apabila memperoleh nilai $90 \%<$ nilai rata-rata $\leq 100 \%$, Baik apabila memperoleh nilai $80 \%<$ nilai rata-rata $\leq 89 \%$, Cukup apabila memperoleh nilai $70 \%<$ nilai rata-rata $\leq 79 \%$ Kurang apabila memperoleh nilai $60 \%<$ nilai rata-rata $\leq 69 \%$, Kurang Sekali apabila memperoleh nilai $0 \%<$ nilai rata-rata $\leq 59 \%$ khususnya pada mata pelajaran Akidah Akhlak yang akan dianalisis dengan rumus sebagai berikut:

$$
\text { Persentase Nilai Rata }- \text { Rata }=\frac{\text { Jumlah skor }}{\text { Skor maksimal }} \times 100 \%
$$




\section{HASIL PENELITIAN DAN PEMBAHASAN}

Hasil observasi aktivitas guru di sekolah MI NW Rumbuk kelas IV pada pelajaran aqidah akhlak dengan tema indahnya akhlak terpuji, menunjukkan bahwa kegiatan pembelajaran menggunakan model pembelajaran picture and picture pada siklus I mendapatkan skor persentase $80 \%$. Berdasarkan kategori penilaian persentase $80 \%$ berada pada kategori baik, namun pada siklus I ada beberapa kegiatan di sekolah MI NW Rumbuk kelas IV pada pelajaran aqidah akhlak dengan tema indahnya akhlak terpuji tidak sesuai dengan perencanaan seperti pada saat memancing siswa kelas IV di MI NW Rumbuk untuk mengingatkan kembali materi sebelumnya, dengan tujuan untuk menggali kembali pengalaman belajar siswa kelas IV di MI NW Rumbuk namun peneliti tidak menjelaskan bahwa Tanya Jawab adalah proses yang penting dalam pembelajaran.

Kemudian pada saat membimbing dan mengarahkan siswa kelas IV MI NW Rumbuk dalam berdiskusi peneliti masih belum bisa mengontrol semua siswa, karena banyaknya siswa yang ingin hanya kelompoknya yang dibimbing dan diarahkan. Kemudian pada saat mengarahkan siswa kelas IV MI NW Rumbuk untuk menanggapi hasil kerja kelompok lain, peneliti tidak menjelaskan bahwa mengeluarkan pendapat adalah hal yang penting dalam melakukan diskusi. Selanjutnya pada saat memancing dan mendorong siswa kelas IV di MI NW Rumbuk untuk bertanya peneliti tidak menjelaskan bahwa bertanya bisa menambahkan pengetahuan dan pengalaman dalam proses belajar dan pada tahap pengelolaan waktu, saat perkenalan tahap-tahap penggunaan model pembelajaran picture and picture masih belum sesuai dengan rencana pembelajaran.

Permasalahan utama adalah kemampuan guru di sekolah MI NW Rumbuk kelas IV, dalam mengelola waktu karena pada saat guru menjelaskan indahnya akhlak terpuji hormat dan patuh kepada kedua orang tua dan guru dengan menggunakan model pembelajaran picture and picture banyak memakan waktu, namun pada siklus II langsung mendapat tindakan tegas sehingga tidak terjadi kesalahan dalam mengelola waktu. Hasil observasi aktivitas guru kelas IV di MI NW Rumbuk pada siklus II menunjukkan bahwa skor persentase 93,88\%. Berdasarkan kategori penilaian persentase $93,88 \%$ berada pada kategori sangat 
baik. Kemampuan guru kelas IV MI NW Rumbuk pada siklus II sudah meningkat dan tidak ada yang perlu diperbaiki namun perlu ditingkatkan lagi.

Pada siklus I hasil observasi aktivitas siswa kelas IV di MI NW Rumbuk menunjukkan bahwa kegiatan pembelajaran menggunakan model pembelajaran picture and picture pada siklus I mendapatkan skor persentase 76,36\%. Berdasarkan kategori penilaian persentase $76,36 \%$ berada pada kategori cukup baik, namun ada beberapa siswa kelas IV MI NW Rumbuk yang belum termotivasi dalam proses pembelajaran dengan menggunakan model pembelajaran picture and picture. Ada beberapa siswa kelas IV di MI NW Rumbuk yang belum menjawab pertanyaan sesuai dengan pengetahuannya.

Kemudian ketepatan siswa dalam berdiskusi dengan kelompok karena ada siswa kelas 4 di MI NW Rumbuk yang tidak senang terhadap anggota kelompoknya sendiri, sehingga berdampak pada kurang tepatnya dalam mengerjakan tugas kelompok serta mempresentasikan tugas kelompok ada beberapa siswa kelas IV di MI NW Rumbuk, yang masih dikatakan malu-malu. Kemudian dalam memberikan tanggapan kepada kelompok lain, siswa kelas IV di MI NW Rumbuk masih belum punya keberanian untuk mengeluarkan pendapatnya.

Masalah utamanya adalah ada sebagian siswa kelas IV di MI NW Rumbuk belum mampu mental dan mengekspresikan pendapatnya serta dalam mempresentasikan hasil diskusi siswa masih malu-malu, karena ketidakbiasaannya membuat siswa merasa canggung terhadap teman-temannya, sehinnga banyak siswa kelas IV di MI NW Rumbuk yang masih kurang aktif dalam proses pembelajaran. Siswa aktif adalah siswa yang aktif dengan anggota badan, pikiran, membuat sesuatu, bermain dan bekerja, tidak hanya duduk dan mendengar. Maka pada siklus II siswa kelas 4 MI NW Rumbuk, difokuskan untuk aktif dalam proses pembelajaran menggunakan model pembelajaran picture and picture baik dalam bertanya maupun menjawab pertanyaan, mempresentasikan serta memberikan tanggapan. Maka observasi aktivitas siswa kelas IV di MI NW Rumbuk pada siklus II menunjukkan bahwa kegiatan pembelajaran menggunakan model pembelajaran picture and picture mendapat skor persentase $90,90 \%$. 
Berdasarkan kategori penilaian persentse 90,90\% berada pada kategori sangat baik. Sehingga aktivitas belajar siswa kelas IV di MI NW Rumbuk sudah berjalan sesuai dengan RPP.

Kemudian untuk menegtahui hasil tes belajar siswa kelas IV MI NW Rumbuk, maka peneliti memberikan tes evaluasi pada setiap siklus berupa tes soal gambar dan isian. Persentase hasil belajar siswa kelas IV MI NW Rumbuk pada materi indahnya akhlak terpuji hormat dan patuh pada siklus I adalah 12 siswa (60\%) yang sudah mencapai nilai KKM dalam kategori baik, dan 8 siswa (40\%) yang belum mencapai KKM 70\%. Hal ini disebabkan beberapa siswa kelas IV di MI NW Rumbuk yang belum memahami dalam menggunakan model pembelajaran picture and picture pada materi indahnya akhlak terpuji hormat dan patuh kepada kedua orang tua dan guru, masih malu-malu bertanya serta siswa kurang teliti dalam menjawab soal.

Selanjutnya hasil belajar siswa kelas IV di MI NW Rumbuk pada siklus II menunjukkan hasil belajar siswa klasikal termasuk kategori tuntas dengan persentase $85 \%$ dengan KKM di MI NW Rumbuk yaitu $70 \%$ untuk pelajaran aqidah akhlak.

\section{KESIMPULAN}

1. Penerapan model pemebelajaran picture and picture untuk meningkatkan minat belajar siswa pada pelajaran aqidah akhlak kelas IV di MI NW Rumbuk adalah pada siklus I menunjukkan 12 siswa sudah mencapai KKM dengan persentase $60 \%$ dan pada siklus II meningkat menjadi 17 siswa dengan persentase $85 \%$.

2. Berdasarkan hasil tes evaluasi siklus I dan siklus II tersebut dapat meningkatkan minat belajar siswa dengan menggunakan model pembelajaran picture and picture di kelas IV pada mata pelajaran aqidah akhlak di MI NW Rumbuk Tahun Pelajaran 2019/2020. 


\section{DAFTAR PUSTAKA}

Hasbullah. Dasar Ilmu Pendidikan. Jakarta: Raja Grafindo Persada. 2005

http;// Safriadi 094. Biogspot.com/2014/05/ model -pembelajaran. Htm. Tanggal 21-7-2019, Jam 11;45 wita.

Imas Kurniasih \& Berlin Sani. Ragam Pengembangan Model Pembelajaran Untuk Meningkatkan Profesional Guru. cet. V.2017

Kementerian Agama. Aqidah Akhlak :Buku Siswa / Kementerian Agama Republik Indonesia. cet. 1. Jakarta.2014

Nasution. Berbagai Pendekatan Dalam Proses Belajar \& Mengajar. cet. VII. Jakarta: PT Bumi Aksara.2000

Suharsimi Arikunto, Suhardjono, Supardi. Penelitian Tindakan Kelas. cet. III. Jakarta: Bumi Aksara.2006

UU RI No. 20 Tahun 2003 Pasal 3 Tentang Sistem Pendidikan Nassonal. Bandung: Citra Umbara 